African Crop Science Journal by African Crop Science Society is licensed under a Creative Commons Attribution 3.0 Uganda License. Based on a work at www.ajol.info/ and www.bioline.org.br/cs DOI: http://dx.doi.org/10.4314/acsj.v25i4.3

\title{
SEMI-DWARF TEF LINES FOR HIGH SEED YIELD AND LODGING TOLERANCE IN CENTRAL ETHIOPIA
}

\author{
H. JIFAR, K. TESFAYE ${ }^{1}$, K. ASSEFA ${ }^{2}$, S. CHANYALEW ${ }^{3}$ and Z. TADELE ${ }^{1,3,4}$ \\ Ethiopian Institute of Agricultural Research, Holetta Agricultural Research Center, P. O. Box 31, \\ Holetta, Ethiopia \\ ${ }^{1}$ Addis Ababa University, Institute of Biotechnology, P. O. Box 32853, Addis Ababa, Ethiopia \\ ${ }^{2}$ Ethiopian Institute of Agricultural Research, Debre Zeit Agricultural Research Center, P. O. Box 32, Debre \\ Zeit, Ethiopia \\ ${ }^{3}$ Institute of Plant Sciences, University of Bern, Altenbergrain 21, 3013 Bern, Switzerland \\ ${ }^{4}$ Center for Development and Environment (CDE), University of Bern, 3012 Bern, Switzerland \\ Corresponding author: Zerihun.tadele@ips.unibe.ch
}

(Received 2 July, 2016; accepted 4 October, 2017)

\begin{abstract}
Tef [Eragrostis tef (Zucc.) Trotter] is the major cereal crop in the Horn of Africa, especially in Ethiopia where it is a staple food for over $60 \%$ of its 90 million population. The crop performs better than other cereal crops under extreme environmental conditions. The grain of tef is not only nutritious but also gluten-free, the cause for celiac disease, which affects humans world wide. The objective of this study was to evaluate the morpho-agronomic performance of newly developed semi-dwarf tef genotypes for grain yield and yield related agronomic traits under diverse environmental conditions. Twenty-four tef lines were evaluated, along with one local and three standard checks, at three locations in the Central Ethiopia. The mean squares due to genotypes, locations and genotype by location interactions were highly significant $(\mathrm{P}<0.01)$ for all the studied traits. Three genotypes, namely RIL- 91, RIL-244 and RIL-11, gave the highest seed yield, ranging between 4.4 to $4.7 \mathrm{tha}^{-1}$, compared to the popular and widely cultivated tef variety called Quncho which gave $4.2 \mathrm{t} \mathrm{ha}^{-1}$. Genotypic and phenotypic coefficients of variations ranged from 0.002 to $173.9 \%$ and from 0.004 to $255.9 \%$, respectively. The highest genetic advance $(20.2 \mathrm{~cm})$ and heritability estimates $(86.7 \%)$ were obtained for plant height indicating that selection for this trait can be made easily. Grain yield showed significant and positive genotypic association with plant height, whole culm and second culm internode length, second culm internode diameter, number of spikelet per panicle and shoot biomass yield. Cluster analysis grouped the genotypes into six distinct classes. The first five principal components with eigenvalues greater than one accounted for $85 \%$ of the total variation. Generally, this study identified tef genotypes with better grain yield and reasonable lodging tolerance for further evaluation and eventual release to the farming communities.
\end{abstract}

Key Words: Eragrostis tef, genetic advance, genotypic coefficients of variations, heritability, phenotypic coefficients of variation, tef

\section{RÉSUMÉ}

Tef [Eragrostis tef (Zucc.) Trotter] est une culture majeure de céréale dans la corne de l'Afrique, particulièrement en Ethiopie où elle est un aliment de base pour plus de $60 \%$ de son 90 million de population. La culture performe mieux que d'autres cultures céréalières dans des conditions environnementales extrêmes. Les grains du tef ne sont pas seulement nutritifs mais aussi ne contiennent pas de gluten, la cause des maladies des céréales, qui affectent les hommes dans le monde. L'objectif de cette étude était d'évaluer la performance morpho-agronomique des 
génotypes semi-nain de tef nouvellement développés pour le rendement en grain et les composantes du rendement sous diverses conditions environnementales. Vingt-quatre lignées de tef étaient évaluées, ensemble avec un local et trois contrôles standards, dans trois locations dans la région centrale de l'Ethiopie. Les carrées moyens dus aux génotypes, locations et aux interactions entre le génotype et l'environnement étaient hautement significatifs $(\mathrm{P}<0.01)$ pour tous les traits étudiés. Trois génotypes, nommés RIL-91, RIL-244 and RIL-11, ont donné les rendements les plus élevés en grain variant de 4,4 à $4,7 \mathrm{t} \mathrm{ha}^{-1}$, comparés à la variété de tef populaire et largement cultivée appelée Ounho qui a donné $4,2 \mathrm{t} \mathrm{ha}^{-1}$. Les coefficients de variation génotypique et phénotypique ont varié de 0,002 à $173,9 \%$ et de 0,004 à $255,9 \%$, respectivement. La plus grande avancée génotypique $(20,2 \mathrm{~cm})$ et les estimations d'héritabilité (86,7\%) étaient obtenues pour la taille de la plante montrant que la sélection pour ce trait peut être faite plus tôt. Le rendement en grain a montré une association significative et positive avec la taille de la plante, la longueur de l'entre-nœud au niveau de la canne intégrale et la seconde canne, le diamètre de la seconde canne de l'entre-nœud, le nombre d'épillet par panicule et le rendement en biomasse de la tige. L'analyse en class a groupé les génotypes en six classes distinctes. Les cinq premières composantes principales avec des valeurs propres supérieures à un ont pris en compte $85 \%$ de la variation totale. En générale, cette étude a identifié des génotypes de tef avec des meilleurs rendements en grains et de tolérance raisonnable à la verse pour davantage évaluation et éventuelle libération aux communautés paysannes.

Mots Clés : Coefficient de variation génotypique, coefficient de variation phénotypique, Eragrostis tef, héritabilité, progrès génétique, tef

\section{INTRODUCTION}

Tef, Eragrostis tef (Zucc.) Trotter, is a major cereal crop in the Horn of Africa, especially in Ethiopia where it is annually cultivated by about 6.5 million smallholder farmers on over three million hectares of land; which is equivalent to $30 \%$ of the area allocated to cereal crops (CSA, 2015). Tef plant perform better than other cereals under extreme climatic conditions, which include both excess and scare moisture. Utilisation of tef grain as food crop has been limited to Ethiopia for quite many centuries. However, it is recently becoming a potential diet of attraction worldwide due to its gluten-free nature (Spaenij-Dekking et al., 2005) and many other health-related benefits.

Tef is an allotetraploid, with $2 n=4 x=40$ chromosomes (Tavassoli, 1986), having its centres of both origin and diversity in Ethiopia (Vavilov, 1951). It is the only cereal cultivated for human consumption in the genus Eragrostis (Tefera and Ketema, 2001; Tefera et al., 2003). Tef is adapted to a wide range of environmental conditions and fits in different cropping systems. It also exhibits, high level of phenotypic plasticity in phenology, morphology and agronomic performance (Assefa et al., 2001). Despite its high importance to the livelihoods of millions of people, the productivity of tef is very low compared to major cereals. The national average yield in Ethiopia for tef is $1.6 \mathrm{t} \mathrm{ha}^{-1}$; while those of maize and wheat are 3.4 and $2.5 \mathrm{t} \mathrm{ha}^{-1}$, respectively (CSA, 2015). Lodging, wider uses of low yielding cultivars, drought and different other stresses are the major factors contributing to the low productivity of tef (Assefa et al., 2011). Lodging affects both the grain yield and quality of tef, and is found to reduce grain yield by approximately 15 to 45\% (Ketema, 1993; Zhu et al., 2012), depending on the weather condition and inherent nature of the variety. Hence, lodging is a crucial problem to address as long as tef production and research is concerned.

Efforts made so far have enabled the development and release of over 35 improved varieties to the farming communities in Ethiopia (MoA, 2014). Some of these varieties provide over $4.5 \mathrm{t} \mathrm{ha}^{-1}$ grain yield under optimum management practices and nonlodging conditions (Tefera and Ketema, 2001). However, development of high yielding and lodging tolerant tef varieties, adapting to the changing climate remains to be the primary focus of tef research. 
Currently, tef researchers are doing their best to tackle lodging, by employing both conventional and modern molecular tools such as TILLING (Targeted Induced Local Lesion in Genome) (Tadele et al., 2010; Esfeld et al., 2013). To this end, tef mutant lines showing promising results regarding lodging tolerance (for instance, Kegne and Kinde mutant tef lines) have been developed in collaboration between the University of Bern and the Ethiopian Institute of Agricultural Research (EIAR). Kegne is linked to the mutation in the Alpha-tubulin-1gene and is characterised by a right-hand twisting phenotype and resistance to microtubule-related drugs like oryzalin (Jost et al., 2015). On the other hand, Kinde has been identified as a promising line, having semidwarf stature, increased numbers of tillers, tolerance to lodging, larger leaf size and deep green phenotype.

In spite of the many desirable traits of Kinde, its grain yield is not as high as improved cultivars such as Quncho. Therefore, introgression of Kinde to the locally adapted commercial tef varieties and cultivars has been made at Debre Zeit Agricultural Research Centre (DZARC) in Ethiopia. Field tests of the progenies of such crosses have also been conducted at DZARC, to identify lines with desired traits for the current and future tef breeding programme. This study was, therefore, conducted to evaluate at representative locations the performance of selected progenies from two independent crosses to Kinde in order to identify promising lines with desirable traits for further improvement of tef.

\section{MATERIALS AND METHODS}

Experimental sites. The field experiment was conducted in 2015 at Holetta, Debre Zeit and AlemTena locations in the Central Highland of Ethiopia, during the main cropping season of 2015. Holetta is located at $9^{\circ} 44^{\prime} \mathrm{N}, 38^{\circ} 30^{\prime} \mathrm{E}$, with an altitude of $2400 \mathrm{~m}$ above sea level (m asl). It receives an average annual rainfall of
$1100 \mathrm{~mm}$, with annual minimum and maximum temperature of 6 and $22{ }^{\circ} \mathrm{C}$, respectively. Debre Zeit is located at $844^{\prime} \mathrm{N}, 38$ 58' E, and an altitude of $1900 \mathrm{~m}$ asl. It receives an annual average rainfall of $851 \mathrm{~mm}$, with annual minimum and maximum temperature of 8.9 to $28.3^{\circ} \mathrm{C}$, respectively. Alem Tena is situated at $8^{\circ} 20^{\prime} \mathrm{N}, 39^{\circ} \mathrm{E}$ and an altitude of $1580 \mathrm{~m}$ asl. This particular location is situated in the Central Rift Valley, known to have poor distribution of rainfall, relatively high temperatures and a light sandy soil with low moisture retaining capacity. The study was conducted on the Nitosols at Holetta, and on a black clay soil (Pellic Vertisol) with high moisture holding capacity at Debre Zeit and on a light sandy soil at Alem Tena.

Plant materials. A total of 28 tef genotypes, including 24 promising recombinant inbred lines (RILs), three standard checks and a local check (Table 1) were evaluated in the field experiment. The RILs were selected from the crosses of Quncho by Kinde and from Kinde by Kaye Murri. The three standard checks were Kinde, a semi-dwarf mutant line identified at the University of Bern from mutagenised tef population; Quncho, a popular tef variety released for high potential areas in Ethiopia; and Tsedey, an improved variety released for moisture-limited environments. The local check was a farmer variety from each location.

Experimental design and management. A Randomised Complete Block Design (RCBD), with three replications was used per site, with a plot size of $1 \mathrm{~m} \mathrm{x} 1 \mathrm{~m}$ at spacing of $0.2 \mathrm{~m}$, $1 \mathrm{~m}$ and $1.5 \mathrm{~m}$ between rows, plots and replication, respectively. Sowing was done at the recommended period for each location (July 14 at Holetta, July -24 at Alem Tena and August 1 at Debre Zeit). Seeds were drilled along the five rows of each plot at the rate of $10 \mathrm{~kg} \mathrm{ha}^{-1}$. Fertiliser was applied according to recommendation for each location $\left(60 \mathrm{~kg} \mathrm{ha}^{-1}\right.$ $\mathrm{P}_{2} \mathrm{O}_{5}$ and $60 \mathrm{~kg} \mathrm{ha}^{-1} \mathrm{~N}$ at Debre Zeit and $60 \mathrm{~kg}$ ha $^{-1} \mathrm{P}_{2} \mathrm{O}_{5}$ and $40 \mathrm{~kg} \mathrm{ha}^{-1} \mathrm{~N}$ at Holetta and Alem 
TABLE 1. Lists of tef genotypes used in a study on semi-dwarf tef lines at Holetta, Debre Zeit and Alem Tena in Ethiopia

\begin{tabular}{llll}
\hline No. & Genotypes & Source & Remarks \\
\hline 1 & RIL-13 & kinde X Key Murri (PVT-2014) & Early set \\
2 & RIL-81 & kinde X Key Murri (PVT-2014) & Early set \\
3 & RIL-302 & kinde X Key Murri (PVT-2014) & Early set \\
4 & RIL-232 & kinde X Key Murri (PVT-2014) & Late set \\
5 & RIL-227 & kinde X Key Murri (PVT-2014) & Late set \\
6 & RIL-181 & kinde X Key Murri (PVT-2014) & Late set \\
7 & RIL-110 & kinde X Key Murri (PVT-2014) & Late set \\
8 & RIL-121 & kinde X Key Murri (AON-2014) & Late set \\
9 & RIL-69 & kinde X Key Murri (AON-2014) & Late set \\
10 & RIL-134 & kinde X K.Murri (AON-2014) & Early set \\
11 & RIL-11 & kinde X K.Murri (AON-2014) & Early set \\
12 & RIL-133 & kinde X Key Murri (AON-2014) & Early set \\
13 & RIL-271 & kinde X K.Murri (AON-2014) & Early set \\
14 & RIL-244 & kinde X Key Murri (AON-2014) & Early set \\
15 & RIL-171 & kinde X Key Murri (AON-2014) & Late set \\
16 & RIL-91 & Quncho X kinde (AON-2014) & Late set \\
17 & RIL-115 & Quncho X kinde (AON-2014) & Late set \\
18 & RIL-180 & Quncho X kinde (AON-2014) & Late set \\
19 & RIL-103 & Quncho X kinde (AON-2014) & Late set \\
20 & RIL-96 & Quncho X kinde (AON-2014) & Late set \\
21 & RIL-132 & Quncho X kinde (AON-2014) & Late set \\
22 & RIL-159 & Quncho X kinde (AON-2014) & Late set \\
23 & RIL-85 & Quncho X kinde (AON-2014) & Early set \\
24 & RIL-137 & Quncho X kinde (AON-2014) & Early set \\
25 & Quncho & Parent (Standard check) & Released for high potential areas \\
26 & kinde & Parent (Standard check) & Mutant parental line \\
27 & Tsedey & Original line & Released for moisture-limited areas \\
28 & Local & Farmers' variety (local check) & \\
\hline & & & \\
& &
\end{tabular}

$\mathrm{AON}=$ Advanced Observation Nursery PVT $=$ Preliminary variety trial RIL = recombinant inbred line

Tena). All amount of $\mathrm{P}_{2} \mathrm{O}_{5}$ was applied at planting in the form of di-ammonium phosphate (DAP: $46 \% \mathrm{P}_{2} \mathrm{O}_{5}$ and $18 \% \mathrm{~N}$ ). However, $\mathrm{N}$ was applied partly at planting (from DAP) and the remainder in the form of urea $(46 \% \mathrm{~N})$ at tillering stage (about 30 -40 days after planting). All other agronomic practices were employed as per the recommendations of the respective test locations.

Data collection. Data on days to panicle emergence, grain filling period, days to maturity, shoot biomass, seed yield, thousand kernel weight, lodging and harvest index, were recorded on plot base. Days to panicle emergence was recorded as the number of days taken from seedling emergence to the appearance of panicles in $50 \%$ of the plants. Similarly, days to maturity was recorded as the number of days taken from seedling emergence to physiological maturity, when $75 \%$ of the straw colour changes to yellowish. On the other hand, grain filling period was computed as the difference between days to maturity and days to panicle mergence.

Shoot biomass was measured as the dry weight of the above ground biomass per plot before threshing; while seed yield refers to the weight of tef grains after threshing. Furthermore, 1000-kernel weight was measured as the weight of 1000 grains of tef. Lodging index was assessed following the 
method suggested by Caldicott and Nuttall (1979), while harvest index was calculated as a ratio of the grain yield to the above ground shoot biomass. Other data such as plant height, panicle length, peduncle length, whole culm and second basal culm internode length and second basal culm internode diameter were recorded for five randomly selected plants from the central rows.

Data analysis. All data were subjected to analysis of variance (ANOVA) for RCBD, as described by Gomez and Gomez (1984), using SAS version 9 (SAS, 2002). Combined analysis of variance was made, after testing for the homogeneity of variances for each trait using the $\mathrm{F}_{\max }$ procedure, by dividing the largest variance to the smallest one. Genotypic and phenotypic coefficients of variations were estimated following the method suggested by Burton and Devane (1953).

Broad sense heritability was estimated as per Allard (1960); whereas genetic advance (GA) and genetic advance as percent of the mean (GAM), assuming selection of the superior $5 \%$ of the genotypes, was estimated as suggested by Singh and Chaudhary (1996). Besides, phenotypic and genotypic correlation coefficients were computed from the components of variance and covariance based on the method described by Singh and Chaudhary (1996), using the CANDISC procedure of SAS system (SAS, 2002).

Genetic diversity assessment was made through cluster analysis and principal component analyses, using SAS Statistical Software Version 9 (SAS, 2002) and Minitab Statistical software, release 15 for windows (Minitab, 2007). Determination of the number of clusters was made based on the Pseudo-F and Pseudo- $T^{2}$ options. Significance of the squared distances was tested as described in the work of Million (2012) for each cluster, against the tabulated $\mathrm{X}^{2}$ values at $\mathrm{p}$ degrees of freedom (where, $\mathrm{p}$ is number of traits considered for clustering) at $5 \%$ probability level. A complete linkage Euclidian distance method was used to construct dendrogramme.

\section{RESULTS}

The combined analysis of variance over three locations, showed that the mean squares due to genotypes, locations and genotype by location interactions were highly significant $(\mathrm{P}<0.01)$ for all the 16 agronomical and morphological traits evaluated (Table 2).

The combined means across three locations was also computed for the 16 traits of 28 tef genotypes and compared (Tables 3 and 4). Based on this result, RIL-91, RIL-244 and RIL11 had grain yields of 4.7, 4.4 and $4.4 \mathrm{tha}^{-1}$ respectively; which was $4.8-11.9 \%$ higher than Quncho (4.2 $\left.\mathrm{t} \mathrm{ha}^{-1}\right)$. Comparison of the mean performances of each trait at the three environments, also clearly showed that some locations were good enough for the accomplishment of some traits; while others were moderate or even the least for the performance of same traits (Tables 3 and 4). Thus, the highest value for phenologic traits such as peduncle length and lodging index were recorded at Holetta; whereas all traits other than days to heading, length of panicle and second basal culm, and lodging index exhibited the least at Alem Tena.

Ranges of traits. The mean, minimum and maximum values for the 16 traits of the tef genotypes were computed based on combined analyses over three locations, and showed the existence of significant amount of variability among the test genotypes for all the studied traits (Table 5). RIL-302 exhibited the shortest plant height and length of the whole culm, panicle and second basal culm. However, the mutant parental line (Kinde) and the original line used for mutagenesis (Tsedey, also known as DZ-Cr-37), had the shortest days to phenologic traits compared to the other genotypes. On the other hand, RIL-91 gave the longest panicle, and the highest number of spikelets per panicle, shoot biomass and grain yield. Similarly, RIL-244 gave the second largest grain yield and the highest harvest index value with moderately short days of phonologic traits. Furthermore, RIL-132 is 
TABLE 2. Mean squares from the combined analysis of variance for 16 agronomical and morphological related traits of 28 tef genotypes evaluated at three locations in Central Ethiopia

\begin{tabular}{|c|c|c|c|c|c|c|}
\hline Traits & $\begin{array}{c}\text { Replications } \\
\text { within locations } \\
(\mathrm{DF}=6)\end{array}$ & $\begin{array}{c}\text { Genotypes }(\mathrm{G}) \\
(\mathrm{DF}=27)\end{array}$ & $\begin{array}{l}\text { Locations (L) } \\
\quad(\mathrm{DF}=2)\end{array}$ & $\begin{array}{c}\mathrm{G} \times \mathrm{L} \text { interaction } \\
(\mathrm{DF}=54)\end{array}$ & $\begin{array}{c}\text { Error } \\
(\mathrm{DF}=162)\end{array}$ & $\mathrm{CV}(\%)$ \\
\hline Days to heading (days) & $3.50 * *$ & $59.77 * * *$ & $10839.83^{* * *}$ & $17.22 * * *$ & 1.22 & 2.30 \\
\hline Grain filling period (days) & $4.56 \mathrm{~ns}$ & $69.77 * * *$ & $24974.26^{* * *}$ & $59.18 * * *$ & 2.30 & 2.90 \\
\hline Days to maturity (days) & $4.35 \mathrm{~ns}$ & $115.28 * * *$ & $64974.47 * * *$ & $62.21 * * *$ & 2.72 & 1.64 \\
\hline Plant height $(\mathrm{cm})$ & $0.28 \mathrm{~ns}$ & $1018.13^{* * *}$ & $2071.83 * * *$ & $53.54 * * *$ & 0.702 & 0.93 \\
\hline Culm length (cm) & $0.28 \mathrm{~ns}$ & $399.74 * * *$ & $1369.17 * * *$ & $91.34 * * *$ & 0.999 & 1.80 \\
\hline Panicle length $(\mathrm{cm})$ & $0.80 \mathrm{~ns}$ & $232.60 * * *$ & $208.43 * * *$ & $68.85 * * *$ & 0.743 & 2.52 \\
\hline Peduncle length $(\mathrm{cm})$ & $0.71 \mathrm{~ns}$ & $34.87 * * *$ & $442.77 * * *$ & $8.75 * * *$ & 0.931 & 5.15 \\
\hline Second basal culm internode length $(\mathrm{cm})$ & $0.77 \mathrm{~ns}$ & $30.61 * * *$ & $20.65 * * *$ & $2.97 * * *$ & 0.458 & 5.94 \\
\hline Second basal culm internode diameter $(\mathrm{mm})$ & $0.16^{*}$ & $0.24 * * *$ & $11.42 * * *$ & $0.185 * * *$ & 0.075 & 13.30 \\
\hline No. of spikelets/ panicle & $0.0018 \mathrm{~ns}$ & $0.063 * * *$ & $1.74 * * *$ & $0.018 * * *$ & 0.001 & 1.38 \\
\hline No. fertile tillers/plant & $0.36^{* *}$ & $1.12 * * *$ & $128.37 * * *$ & $1.03^{* * *}$ & 0.12 & 10.50 \\
\hline Shoot biomass $\left(\mathrm{t} \mathrm{ha}^{-1}\right)$ & $0.0015 \mathrm{~ns}$ & $0.061 * * *$ & $2.10 * * *$ & $0.016 * * *$ & 0.0007 & 2.45 \\
\hline Grain yield $\left(\mathrm{t} \mathrm{ha}^{-1}\right)$ & $0.0001 \mathrm{~ns}$ & $0.044 * * *$ & $2.74 * * *$ & $0.011 * * *$ & 0.0005 & 3.70 \\
\hline Harvest index (\%) & $1.67 \mathrm{~ns}$ & $53.81 * * *$ & $2724.92 * * *$ & $26.34 * * *$ & 1.40 & 4.31 \\
\hline Lodging index (\%) & $2.93 \mathrm{~ns}$ & $447.13 * * *$ & $5130.57 * * *$ & $68.85 * * *$ & 4.66 & 3.36 \\
\hline Thousand kernel weight $(\mathrm{g})$ & $0.16 \mathrm{~ns}$ & $19.77 * * *$ & $130.04 * * *$ & $13.30 * * *$ & 0.235 & 1.80 \\
\hline
\end{tabular}

$\mathrm{DF}=$ Degrees of freedom; $* * *$ and $* * *=$ significant at $\mathrm{P}<0.05, \mathrm{P}<0.01$ and $\mathrm{P}<0.001$, respectively; ns $=$ Non-significant at $\mathrm{P}<0.05$ 
TABLE 3. Mean of eight agronomical traits of 28 tef genotypes evaluated at Holetta, Debre Zeit and Alem Tena in Ethiopia

\begin{tabular}{|c|c|c|c|c|c|c|c|c|c|}
\hline No. & Genotypes & $\begin{array}{l}\text { Days to } \\
\text { heading }\end{array}$ & $\begin{array}{l}\text { Grain filling } \\
\text { period (days) }\end{array}$ & $\begin{array}{l}\text { Days to } \\
\text { maturity }\end{array}$ & $\begin{array}{l}\text { Shoot biomass } \\
\text { yield }\left(\mathrm{kg} \mathrm{ha}^{-1}\right)\end{array}$ & $\begin{array}{c}\text { Grain yield } \\
\left(\mathrm{kg} \mathrm{ha}^{-1}\right)\end{array}$ & $\begin{array}{l}\text { Harvest } \\
\text { index }(\%)\end{array}$ & $\begin{array}{l}\text { 1000-kernel } \\
\text { weight (mg) }\end{array}$ & $\begin{array}{l}\text { Lodging } \\
\text { index }\end{array}$ \\
\hline 1 & RIL-13 & 45.44 & 53.44 & 98.89 & 11.40 & 3.13 & 27.29 & 22.77 & 60.55 \\
\hline 2 & RIL-81 & 52.1 & 50.22 & 102.33 & 10.20 & 2.58 & 24.03 & 23.88 & 74.36 \\
\hline 3 & RIL-302 & 49.22 & 50.89 & 100.19 & 8.34 & 2.29 & 25.13 & 22.73 & 60.12 \\
\hline 4 & RIL-232 & 47.44 & 58.56 & 106.00 & 11.02 & 3.44 & 29.93 & 22.79 & 72.47 \\
\hline 5 & RIL-227 & 47.00 & 53.00 & 99.96 & 11.18 & 3.45 & 29.83 & 22.24 & 63.56 \\
\hline 6 & RIL-181 & 46.89 & 51.81 & 97.59 & 12.92 & 3.78 & 27.77 & 22.70 & 53.82 \\
\hline 7 & RIL-110 & 48.44 & 54.89 & 103.56 & 12.80 & 3.78 & 29.16 & 22.64 & 68.36 \\
\hline 8 & RIL-121 & 44.67 & 51.26 & 95.93 & 11.56 & 3.62 & 29.88 & 22.58 & 65.22 \\
\hline 9 & RIL-69 & 48.89 & 52.37 & 101.26 & 12.64 & 3.26 & 24.90 & 22.94 & 66.68 \\
\hline 10 & RIL-134 & 48.44 & 48.89 & 97.33 & 7.54 & 2.07 & 25.79 & 28.80 & 71.10 \\
\hline 11 & RIL-11 & 44.89 & 53.30 & 98.19 & 12.72 & 4.35 & 32.55 & 27.00 & 66.10 \\
\hline 12 & RIL-133 & 47.26 & 51.89 & 99.19 & 13.29 & 3.92 & 28.60 & 22.35 & 67.19 \\
\hline 13 & RIL-271 & 48.00 & 54.26 & 102.26 & 13.44 & 3.73 & 27.06 & 22.08 & 63.51 \\
\hline 14 & RIL-244 & 44.11 & 51.70 & 95.81 & 13.59 & 4.47 & 32.19 & 22.37 & 64.98 \\
\hline 15 & RIL-171 & 48.22 & 53.48 & 101.70 & 12.87 & 3.60 & 27.01 & 22.25 & 70.46 \\
\hline 16 & RIL-91 & 50.44 & 56.44 & 105.78 & 17.13 & 4.72 & 27.29 & 22.91 & 59.64 \\
\hline 17 & RIL-115 & 47.04 & 50.11 & 97.22 & 10.78 & 3.28 & 29.93 & 22.93 & 68.51 \\
\hline 18 & RIL-180 & 47.04 & 50.44 & 97.70 & 13.26 & 3.38 & 25.03 & 22.65 & 52.56 \\
\hline 19 & RIL-103 & 52.56 & 54.56 & 107.11 & 15.15 & 3.97 & 24.55 & 22.20 & 58.58 \\
\hline 20 & RIL-96 & 49.89 & 51.11 & 100.67 & 11.87 & 3.16 & 24.74 & 22.34 & 65.53 \\
\hline 21 & RIL-132 & 48.63 & 49.56 & 98.22 & 13.82 & 3.99 & 28.29 & 24.28 & 56.25 \\
\hline 22 & RIL-159 & 47.67 & 50.33 & 98.00 & 12.71 & 3.90 & 29.39 & 22.90 & 77.03 \\
\hline 23 & RIL-85 & 48.56 & 55.56 & 104.19 & 13.14 & 3.55 & 24.81 & 25.62 & 60.60 \\
\hline 24 & RIL-137 & 53.00 & 48.33 & 101.00 & 14.34 & 3.65 & 23.68 & 22.17 & 65.75 \\
\hline 25 & Quncho & 53.11 & 52.44 & 105.56 & $15.33 \mathrm{~b}$ & 4.17 & 25.61 & 22.31 & 75.28 \\
\hline 26 & Kinde & 48.33 & 47.22 & 95.56 & $7.39 \mathrm{o}$ & 1.98 & 26.79 & 22.94 & 47.14 \\
\hline
\end{tabular}


also among the high yielding genotypes and had the largest diameter of the second basal culm internode.

Estimates of genetic variability. Estimates of variability parameters are presented in Table 6 . The highest genotypic coefficients of variation (GCV) were estimated for thousand kernel weight (173\%), plant height (123\%) and culm length $(67.9 \%)$; whereas the least were noted for number of spikelets per panicle $(0.004 \%)$, shoot biomass $(0.092 \%)$ and grain yield $(0.227 \%)$ in that order. Likewise, the highest phenotypic coefficients of variation (PCV) values of 143.6, 134.4 and 128.4\% were estimated for plant height, panicle length and culm length, respectively. However, the least PCV estimates of $0.002,0.05$ and $0.126 \%$ were obtained for number of spikelets per panicle, shoot biomass and grain yield, respectively. The number of spikelets per panicle, shoot biomass and grain yield had the lowest values for both GCV and PCV.

Estimation of the broad sense heritability (H) and genetic advance (GA) showed the highest genetic advance coupled with high heritability value for plant height $(20.2 \mathrm{~cm}$, $86.7 \%$ ) and thousand seed weight (11.6 mg, $68.1 \%)$. On the other hand, a high heritability value, accompanied with low genetic advance was estimated for second culm length $(78.6 \%$, $3.3 \mathrm{~cm})$.

Association of traits. The correlations among the different grain yield and lodging related traits of the test tef genotypes are presented in Tables 7 and 8. There was positive and highly significant $(\mathrm{P}<0.01)$ phenotypic association between grain yield and of all traits, other than days to heading. Besides, a significant and positive genotypic association was detected between grain yield and all traits, except days to heading and maturity, peduncle length, number of fertile tillers per plant, lodging index and thousand kernel weight. Similarly, shoot biomass had positive and highly significant $(\mathrm{P}<0.01)$ phenotypic association with all traits, other than thousand 
TABLE 4. Mean of eight morphological traits of 28 tef genotypes evaluated at Holetta, Debre Zeit and Alem Tena in Ethiopia

\begin{tabular}{|c|c|c|c|c|c|c|c|c|c|}
\hline No. & Genotype & $\begin{array}{l}\text { Plant height } \\
\quad(\mathrm{cm})\end{array}$ & $\begin{array}{c}\text { Culm } \\
\text { length }(\mathrm{cm})\end{array}$ & $\begin{array}{c}\text { Panicle } \\
\text { length }(\mathrm{cm})\end{array}$ & $\begin{array}{l}\text { Peduncle } \\
\text { length }(\mathrm{cm})\end{array}$ & $\begin{array}{l}\text { Second basal } \\
\text { culm internode } \\
\text { length }(\mathrm{cm})\end{array}$ & $\begin{array}{c}\text { Second basal } \\
\text { culm internode } \\
\text { dia. }(\mathrm{mm})\end{array}$ & $\begin{array}{l}\text { Number of } \\
\text { fertile tillers/ } \\
\text { plant }\end{array}$ & $\begin{array}{l}\text { Number of } \\
\text { spikelets/ } \\
\text { panicle }\end{array}$ \\
\hline 1 & RIL-13 & 85.88 & 53.51 & 32.43 & 16.25 & 11.21 & 2.03 & 3.05 & 315.10 \\
\hline 2 & RIL-81 & 82.68 & 52.01 & 30.87 & 15.69 & 10.08 & 2.00 & 3.27 & 320.85 \\
\hline 3 & RIL-302 & 61.20 & 34.60 & 26.84 & 17.61 & 6.89 & 2.00 & 3.17 & 241.68 \\
\hline 4 & RIL-232 & 88.41 & 59.97 & 28.03 & 21.89 & 12.01 & 1.73 & 2.83 & 240.30 \\
\hline 5 & RIL-227 & 88.94 & 56.37 & 32.04 & 19.78 & 9.82 & 2.13 & 3.63 & 277.44 \\
\hline 6 & RIL-181 & 93.58 & 56.95 & 36.63 & 18.01 & 11.69 & 2.04 & 3.82 & 315.53 \\
\hline 7 & RIL-110 & 89.36 & 54.38 & 34.98 & 17.54 & 11.38 & 2.28 & 3.99 & 380.22 \\
\hline 8 & RIL-121 & 84.02 & 52.08 & 31.95 & 86.25 & 10.26 & 2.16 & 4.13 & 285.23 \\
\hline 9 & RIL-69 & 92.32 & 54.74 & 37.88 & 19.16 & 10.47 & 2.15 & 3.40 & 437.01 \\
\hline 10 & RIL-134 & 73.27 & 46.31 & 26.88 & 18.72 & 8.03 & 1.72 & 3.33 & 293.37 \\
\hline 11 & RIL-11 & 86.83 & 56.99 & 29.84 & 20.36 & 11.50 & 2.03 & 3.34 & 282.09 \\
\hline 12 & RIL-133 & 88.11 & 58.31 & 29.80 & 19.74 & 11.22 & 2.00 & 3.03 & 290.27 \\
\hline 13 & RIL-271 & 94.91 & 58.05 & 36.86 & 23.36 & 12.3 & 2.13 & 3.00 & 349.89 \\
\hline 14 & RIL-244 & 86.00 & 55.53 & 30.47 & 20.78 & 11.34 & 2.04 & 3.80 & 307.77 \\
\hline 15 & RIL-171 & 90.64 & 59.35 & 31.28 & 17.58 & 12.76 & 2.14 & 3.55 & 419.34 \\
\hline 16 & RIL-91 & 108.43 & 63.54 & 44.88 & 17.75 & 14.59 & 2.13 & 3.25 & 447.10 \\
\hline 17 & RIL-115 & 87.19 & 52.29 & 34.90 & 18.87 & 11.95 & 1.71 & 3.02 & 288.22 \\
\hline 18 & RIL-180 & 90.31 & 57.18 & 33.13 & 21.53 & 12.03 & 2.14 & 3.63 & 328.77 \\
\hline 19 & RIL-103 & 101.80 & 61.94 & 39.86 & 196.25 & 13.22 & 2.21 & 3.15 & 461.37 \\
\hline 20 & RIL-96 & 93.90 & 55.03 & 38.87 & 18.32 & 11.78 & 1.86 & 3.41 & 397.10 \\
\hline 21 & RIL-132 & 99.54 & 63.62 & 35.92 & 22.28 & 12.93 & 2.33 & 2.71 & 353.69 \\
\hline 22 & RIL-159 & 101.44 & 57.48 & 43.96 & 18.04 & 12.04 & 2.18 & 3.34 & 382.91 \\
\hline 23 & RIL-85 & 94.22 & 59.11 & 35.11 & 20.17 & 11.95 & 1.97 & 3.17 & 341.80 \\
\hline 24 & RIL-137 & 99.77 & 62.56 & 37.21 & 18.20 & 13.18 & 2.14 & 3.03 & 379.33 \\
\hline 25 & Quncho & 108.78 & 64.25 & 44.53 & 18.74 & 14.87 & 2.29 & 2.64 & 420.44 \\
\hline 26 & Kinde & 66.72 & 39.53 & 27.19 & 15.32 & 7.18 & 1.92 & 3.08 & 273.09 \\
\hline
\end{tabular}


kernel weight. Likewise, a significant and positive genotypic association was also detected between shoot biomass and all traits, except days to heading, number of fertile tillers, harvest index, lodging index and thousand kernel weight. Surprisingly, lodging which is a major constraint to tef production had no significant $(\mathrm{P}<0.05)$ genotypic association with all the studied traits. However, it had a positive and significant $(\mathrm{P}<0.01)$ phenotypic association with days to heading and maturity, culm and peduncle length as well as shoot biomass and grain yield.

Cluster and divergence analysis. The 28 tef genotypes in the current study were grouped into six distinct clusters, based on 16 traits, using the average linkage method (Fig. 1). The number of genotypes per each cluster ranged from two genotypes for cluster 4 up to 9 genotypes for cluster 1 . Cluster 2 and 3 had seven and four genotypes, respectively; whereas cluster 5 and 6 had three genotypes each. The different genotypes grouped within a given cluster were assumed to be more closely related in terms of the studied traits than those genotypes grouped into different clusters.

A commercial variety released for the low moisture stress areas (Tsedey) was grouped into cluster 1, along with eight recombinant inbred lines. On the other hand, a commercial variety released for the high potential areas (Quncho) was grouped into cluster 5 along with two recombinant inbred lines (RIL-91 and RIL-103). Genotypes in cluster 1 had relatively shorter phonologic traits; and an average performance for the remaining traits; whereas those in cluster 5 had high value for almost more than $50 \%$ of the traits under investigation. Compared to genotypes in other clusters, those in cluster 5 had higher values for days to heading and maturity, plant height, culm and panicle length, spikelet number per panicle as well as shoot biomass and grain yield. On the other hand, cluster 6 consisted of the semidwarf parental line (kinde), along with RIL302 and RIL-134, which had the least values 
TABLE 5. Ranges and mean values of 16 traits of tef genotypes evaluated at Holetta, Debre Zeit and Alem Tena in Ethiopia

\begin{tabular}{|c|c|c|c|c|c|}
\hline \multirow[t]{2}{*}{ Traits } & \multicolumn{2}{|c|}{ Minimum } & \multicolumn{2}{|c|}{ Maximum } & \multirow[t]{2}{*}{ Mean } \\
\hline & Value & Genotype & Value & Genotype & \\
\hline Days to heading & 42.89 & Tsedey & 53.11 & Quncho & 48.08 \\
\hline Grain Filling period (days) & 47.22 & kinde & 58.56 & RIL-232 & 52.35 \\
\hline Days to maturity & 93.78 & Tsedey & 107.11 & RIL-103 & 100.34 \\
\hline Plant height $(\mathrm{cm})$ & 61.20 & RIL-302 & 108.78 & Quncho & 89.69 \\
\hline Culm length $(\mathrm{cm})$ & 34.60 & RIL-302 & 64.25 & Quncho & 55.44 \\
\hline Panicle length $(\mathrm{cm})$ & 26.84 & RIL-302 & 44.89 & RIL-91 & 34.24 \\
\hline Peduncle length $(\mathrm{cm})$ & 15.32 & kinde & 23.36 & RIL-271 & 18.74 \\
\hline Second basal culm internode length $(\mathrm{cm})$ & 6.89 & RIL-302 & 14.87 & Quncho & 11.39 \\
\hline Second basal culm internode diameter $(\mathrm{mm})$ & 1.71 & RIL-115 & 2.33 & RIL-132 & 2.06 \\
\hline Number of fertile tillers/plant & 2.64 & Quncho & 4.13 & RIL-121 & 3.32 \\
\hline Number of spikelets/panicle & 213.62 & Local & 461.37 & RIL-91 & 334.08 \\
\hline Shoot biomass $\left(\mathrm{t} \mathrm{ha}^{-1}\right)$ & 7.39 & kinde & 17.13 & RIL-91 & 12.35 \\
\hline Grain yield $\left(\mathrm{t} \mathrm{ha}^{-1}\right)$ & 1.98 & kinde & 4.73 & RIL-91 & 3.53 \\
\hline Harvest index $(\%)$ & 23.68 & RIL-137 & 32.55 & RIL-244 & 27.47 \\
\hline Thousand kernel weight (mg) & 23.88 & RIL-81 & 30.82 & Local & 26.90 \\
\hline Lodging index $(\%)$ & 47.14 & kinde & 77.03 & RIL-159 & 64.28 \\
\hline
\end{tabular}

TABLE 6. Estimates and genotypic coefficient of variation and heritability as percent of mean for 16 traits of tef genotypes

\begin{tabular}{lccccc}
\hline Traits & $\begin{array}{c}\text { Phenotypic } \\
\text { coefficient } \\
\text { of variation } \\
\text { (PCV) }(\%)\end{array}$ & $\begin{array}{c}\text { Genotypic } \\
\text { coefficient } \\
\text { of variation } \\
(\mathrm{GCV})(\%)\end{array}$ & $\begin{array}{c}\text { Broad sense } \\
\text { heritability } \\
(\%)\end{array}$ & $\begin{array}{c}\text { Genetic } \\
\text { advance } \\
(\mathrm{GA})\end{array}$ & $\begin{array}{c}\text { GA as } \\
\text { percent } \\
\text { of the means }\end{array}$ \\
\hline Days to heading & 23.67 & 12.30 & 51.95 & 3.61 & 7.51 \\
Grain filling period (days) & 47.00 & 10.30 & 21.91 & 2.24 & 4.28 \\
Days to maturity & 30.33 & 10.27 & 33.85 & 3.85 & 3.83 \\
Plant height (cm) & 143.58 & 123.86 & 86.26 & 20.17 & 22.48 \\
Culm length (cm) & 128.40 & 73.88 & 57.54 & 10.00 & 18.04 \\
Panicle length (cm) & 134.42 & 67.87 & 50.49 & 7.06 & 20.61 \\
Peduncle length (cm) & 33.04 & 18.58 & 56.23 & 2.88 & 15.38 \\
Second basal culm internode length (cm) & 36.40 & 28.60 & 78.57 & 3.30 & 28.93 \\
Second basal culm internode dia. (mm) & 2.88 & 0.692 & 24.06 & 0.12 & 5.86 \\
No. of fertile tillers/plant & 14.46 & 2.276 & 15.74 & 0.22 & 6.77 \\
No. of spikelet/panicle & 0.004 & 0.002 & 52.00 & 0.12 & 0.04 \\
Shoot biomass yield (kg ha $\left.{ }^{-1}\right)$ & 0.092 & 0.050 & 54.22 & 0.12 & 0.96 \\
Grain yield (kg ha $\left.{ }^{-1}\right)$ & 0.227 & 0.126 & 55.56 & 0.10 & 2.90 \\
Harvest index (\%) & 48.67 & 17.84 & 36.65 & 2.76 & 10.05 \\
Thousand kernel weight (mg) & 255.39 & 173.93 & 68.10 & 11.63 & 43.23 \\
Lodging index & 9.44 & 2.62 & 27.80 & 1.41 & 2.19 \\
\hline
\end{tabular}


TABLE 7. Genotypic (upper diagonal) and phenotypic (lower diagonal) correlations among 8 traits of 28 semi dwarf tef genotypes at Holetta, Debre Zeit and Alem Tena in Ethiopia

\begin{tabular}{|c|c|c|c|c|c|c|c|c|}
\hline Variable & DH & $\mathrm{DM}$ & $\mathrm{PH}$ & $\mathrm{CL}$ & PL & PdL & SCL & SCD \\
\hline Days to heading (DH) & 1 & $0.64 * * *$ & $0.36 \mathrm{~ns}$ & $0.23 \mathrm{~ns}$ & $0.45^{*}$ & $-0.14 \mathrm{~ns}$ & $0.28 \mathrm{~ns}$ & $0.16 \mathrm{~ns}$ \\
\hline Days to maturity (DM) & $0.92 * * *$ & 1 & $0.48 * *$ & $0.44 * *$ & $0.43^{*}$ & $0.066 \mathrm{~ns}$ & $0.47 *$ & $0.21 \mathrm{~ns}$ \\
\hline Plant height $(\mathrm{cm})(\mathrm{PH})$ & $0.03 \mathrm{~ns}$ & $0.11 \mathrm{~ns}$ & 1 & $0.93 * * *$ & $0.87 * * *$ & $0.28 \mathrm{~ns}$ & $0.94 * * *$ & $0.50^{* * *}$ \\
\hline Culm length (cm) (CL) & $0.11 \mathrm{~ns}$ & $0.20 * *$ & $0.84 * * *$ & 1 & $0.63 * * *$ & $0.43^{*}$ & $0.93 * * *$ & $0.42 *$ \\
\hline Panicle length $(\mathrm{cm})(\mathrm{PL})$ & $-0.09 \mathrm{~ns}$ & $-0.08 \mathrm{~ns}$ & $0.69 * * *$ & $0.20 * *$ & 1 & $0.01 \mathrm{~ns}$ & $0.74 * * *$ & $0.50 * *$ \\
\hline Peduncle length $(\mathrm{cm})(\mathrm{Pdl})$ & $0.32 * * *$ & $0.46^{* * *}$ & $0.30 * * *$ & $0.42 * * *$ & $-0.02 \mathrm{~ns}$ & 1 & $0.31 \mathrm{~ns}$ & $0.003 \mathrm{~ns}$ \\
\hline Second basal culm internode length $(\mathrm{cm})(\mathrm{SCL})$ & $-0.11 \mathrm{~ns}$ & $-0.10 \mathrm{~ns}$ & $0.76^{* * *}$ & $0.66 * * *$ & $0.51 * * *$ & $0.15^{*}$ & 1 & $0.42 *$ \\
\hline Second basal culm internode dia. (mm) (SCD) & $-0.17 * *$ & $0.01 \mathrm{~ns}$ & $0.39 * * *$ & $0.36 * * *$ & $0.22 * * *$ & $0.23 * * *$ & $0.20 * *$ & 1 \\
\hline No. of spikelet/panicle (SPK) & $-0.26 * * *$ & $-0.09 \mathrm{~ns}$ & $0.60 * * *$ & $0.46 * * *$ & $0.48 * * *$ & $0.23 * *$ & $0.38 * * *$ & $0.59 * * *$ \\
\hline No. of fertile tillers/plant (FT) & $-0.39 * * *$ & $-0.15^{*}$ & $0.22 * * *$ & $0.20 * * *$ & $0.13 *$ & $0.21 * * *$ & $-0.01 \mathrm{~ns}$ & $0.57 * * *$ \\
\hline Shoot biomass yield $\left(\mathrm{kg} \mathrm{ha}^{-1}\right)(\mathrm{SBM})$ & $0.23 * * *$ & $0.44 * * *$ & $0.67 * * *$ & $0.66 * * *$ & $0.33 * * *$ & $0.54 * * *$ & $0.46^{* * *}$ & $0.56^{* * *}$ \\
\hline Grain yield $(\mathrm{GY})\left(\mathrm{kg} \mathrm{ha}^{-1}\right)$ & $0.06 \mathrm{~ns}$ & $0.32 * * *$ & $0.59 * * *$ & $0.61 * * *$ & $0.26 * * *$ & $0.55 * * *$ & $0.36 * * *$ & $0.62 * * *$ \\
\hline Harvest index (\%) & $-0.11 \mathrm{~ns}$ & $0.18 * *$ & $0.26 * * *$ & $0.35 * * *$ & $0.01 \mathrm{~ns}$ & $0.46 * * *$ & $0.02 \mathrm{~ns}$ & $0.52 * * *$ \\
\hline Lodging index (LG) & $0.58 * * *$ & $0.62 * * *$ & $0.12 \mathrm{~ns}$ & $0.19 * *$ & $-0.04 n s$ & $0.27 * * *$ & $-0.02 \mathrm{~ns}$ & $-0.08 n s$ \\
\hline Thousand kernel weight (mg) (TKW) & $-0.35 * * *$ & $-0.23 * * *$ & $0.04 \mathrm{~ns}$ & $0.03 \mathrm{~ns}$ & $0.03 \mathrm{~ns}$ & $-0.05 \mathrm{~ns}$ & $-0.01 \mathrm{~ns}$ & $0.23 * * *$ \\
\hline
\end{tabular}

$*, * *$ and $* * *=$ significant at $\leq 0.05$, at $\leq 0.01$ and at $\leq 0.001$, respectively 
TABLE 8. Genotypic (upper diagonal) and phenotypic (lower diagonal) correlations among 7 traits of 28 semi dwarf tef genotypes

\begin{tabular}{|c|c|c|c|c|c|c|c|}
\hline Variable & SPK & FT & SBM & GY & $\mathrm{HI}$ & LG & TKW \\
\hline Days to heading (DH) & $0.57 * *$ & $-0.51 * *$ & $0.20 \mathrm{~ns}$ & $-0.14 n s$ & $-0.76^{* * *}$ & $0.15 \mathrm{~ns}$ & $-0.38 *$ \\
\hline Days to maturity(DM) & $0.39 *$ & $-0.38 \mathrm{~ns}$ & $0.43^{*}$ & $0.21 \mathrm{~ns}$ & $-0.40 *$ & $0.17 \mathrm{~ns}$ & $-0.08 \mathrm{~ns}$ \\
\hline Plant height $(\mathrm{cm})(\mathrm{PH})$ & $0.70 * * *$ & $-0.21 \mathrm{~ns}$ & $0.89 * * *$ & $0.76 * * *$ & $-0.08 \mathrm{~ns}$ & $0.19 \mathrm{~ns}$ & $-0.14 n s$ \\
\hline Culm length $(\mathrm{cm})(\mathrm{CL})$ & $0.55 * *$ & $-0.21 \mathrm{~ns}$ & $0.86 * * *$ & $0.78 * * *$ & $0.05 \mathrm{~ns}$ & $0.21 \mathrm{~ns}$ & $-0.18 \mathrm{~ns}$ \\
\hline Panicle length $(\mathrm{cm})(\mathrm{PL})$ & $0.74 * * *$ & $-0.17 n s$ & $0.74 * * *$ & $0.55 * *$ & $-0.23 n s$ & $0.13 \mathrm{~ns}$ & $-0.066 n s$ \\
\hline Peduncle length $(\mathrm{cm})(\mathrm{Pdl})$ & $-0.05 \mathrm{~ns}$ & $-0.23 n s$ & $0.28 \mathrm{~ns}$ & $0.35 \mathrm{~ns}$ & $0.23 \mathrm{~ns}$ & $0.02 \mathrm{~ns}$ & $-0.21 \mathrm{~ns}$ \\
\hline Second basal culm internode length $(\mathrm{cm})(\mathrm{SCL})$ & $0.61 * * *$ & $-0.22 n s$ & $0.90 * * *$ & $0.80 * * *$ & $-0.001 \mathrm{~ns}$ & $0.19 \mathrm{~ns}$ & $-0.02 \mathrm{~ns}$ \\
\hline Second basal culm internode dia. (mm) (SCD) & $0.46^{*}$ & $0.13 \mathrm{~ns}$ & $0.62 * * *$ & $0.52 * *$ & $-0.05 \mathrm{~ns}$ & $-0.11 \mathrm{~ns}$ & $-0.04 n s$ \\
\hline No. of spikelet/panicle (SPK) & 1 & $-0.09 n s$ & $0.63 * * *$ & $0.38^{*}$ & $-0.42 *$ & $0.16 \mathrm{~ns}$ & $-0.25 \mathrm{~ns}$ \\
\hline No. of fertile tillers/plant (FT) & $0.67 * * *$ & 1 & $-0.05 \mathrm{~ns}$ & $0.10 \mathrm{~ns}$ & $0.31 \mathrm{~ns}$ & $-0.01 \mathrm{~ns}$ & $0.39 \mathrm{~ns}$ \\
\hline Shoot biomass yield $\left(\mathrm{kg} \mathrm{ha}^{-1}\right)(\mathrm{SBM})$ & $0.63 * * *$ & $0.44 * * *$ & 1 & $0.90 * * *$ & $0.02 \mathrm{~ns}$ & $0.03 \mathrm{~ns}$ & $-0.03 n s$ \\
\hline Grain yield (GY) $\left(\mathrm{kg} \mathrm{ha}^{-1}\right)$ & $0.67 * * *$ & $0.60 * * *$ & $0.93 * * *$ & 1 & $0.45 * 1$ & $0.12 \mathrm{~ns}$ & $0.08 \mathrm{~ns}$ \\
\hline Harvest index (\%) & $0.50 * * *$ & $0.66 * * *$ & $0.54 * * *$ & $0.78 * * *$ & 1 & $0.14 \mathrm{~ns}$ & $0.27 \mathrm{~ns}$ \\
\hline Lodging index (LG) & $-0.07 \mathrm{~ns}$ & $-0.13^{*}$ & $0.21 * *$ & $0.17 * *$ & $0.12 \mathrm{~ns}$ & 1 & $0.11 \mathrm{~ns}$ \\
\hline Thousand kernel weight (mg) (TKW) & $0.19 * *$ & $0.43 * * *$ & $0.09 \mathrm{~ns}$ & $0.19 * *$ & $0.27 * * *$ & $-0.09 \mathrm{~ns}$ & 1 \\
\hline
\end{tabular}

$*, * *$ and $* * *=$ significant at $\leq 0.05$, at $\leq 0.01$ and at $\leq 0.001$, respectively 


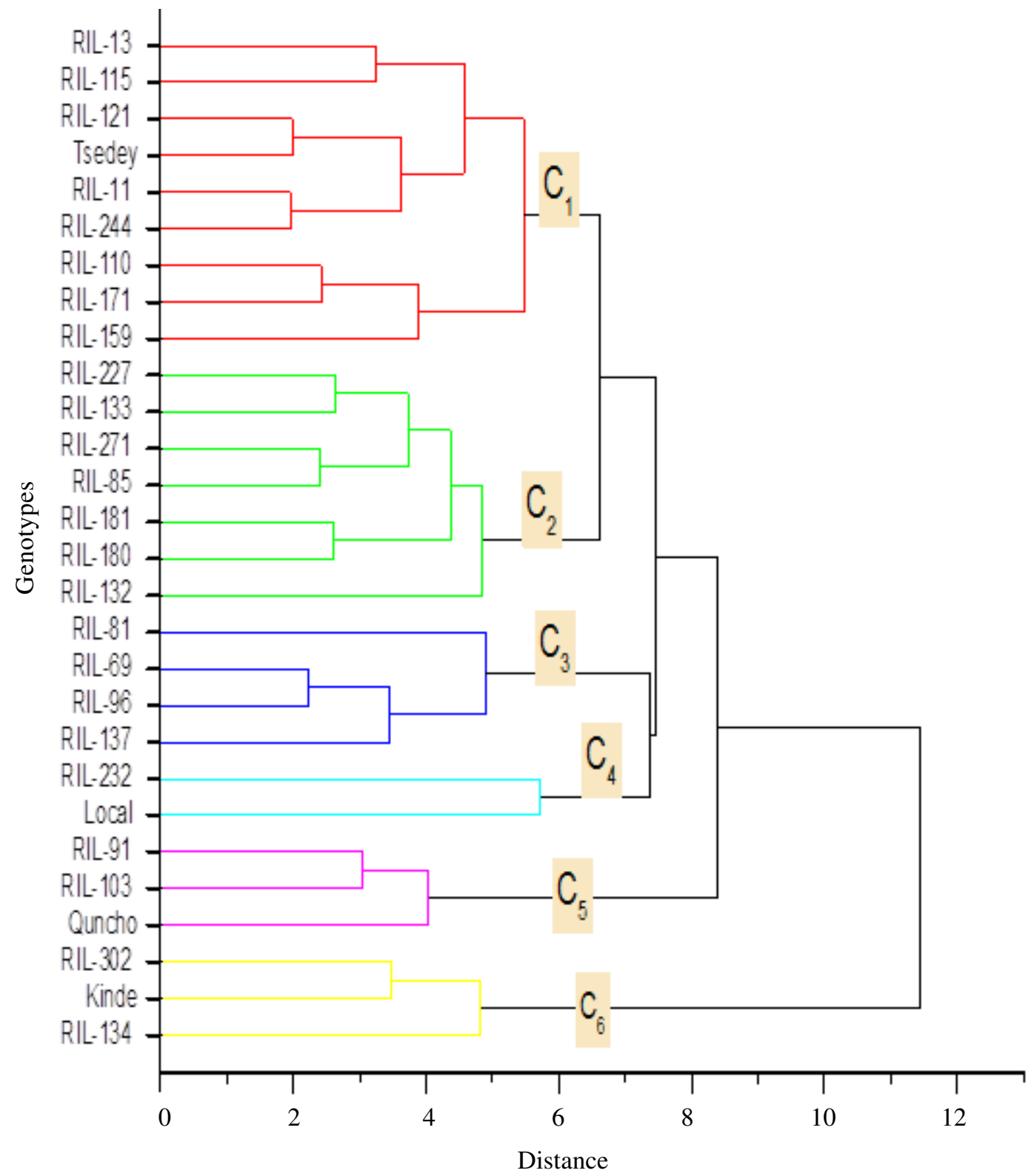

Figure 1. Dendrogram showing the clustering patterns of 28 tef genotypes evaluated for 16 grain yield and lodging related traits of tef at Holetta, Debre Zeit and Alem Tena in Ethiopia. 
for nine of the 16 studied traits (Table 9). Among others, they had the shortest days to maturity and for all growth related traits, as well as smaller values of shoot biomass, grain yield and lodging index. Genotypes in certain clusters showed preferential advantages in specific agronomic traits, which can be used for further development into improved varieties. For instance, genotypes in cluster 6 possess lodging-tolerance related traits; while those in cluster 5 are associated to high grain yield.

The distance analysis was estimated for all the 15 possible pairs of clusters in the current study and is presented in Table 10. A maximum distance was observed between cluster 4 and $6\left(D^{2}=602.7\right)$; followed by cluster 1 and $6\left(D^{2}=501.6\right)$ and cluster 5 and 6 (462.6). On the other hand, the minimum distance was obtained between cluster 2 and $3\left(D^{2}=45.3\right)$; followed by that between cluster 2 and $5\left(D^{2}=49.4\right)$.

Principal component analysis. The patterns of variations among 28 tef genotypes were assessed simultaneously based on the 16 studied traits. The result showed that the first five principal components, with eigen value greater than one, accounted for $85 \%$ of the total variations among the studied genotypes (Table 11). Out of this, the first principal component alone had explained $41.3 \%$ of the gross variability among the genotypes evaluated mainly due to variations in plant height, second culm and whole culm length. On the other hand, about $17.8 \%$ of the total genetic variation in the present study was accounted for the second principal component due mainly to variations in days to heading and maturity, grain yield and number of spikelet per panicle. Furthermore, the third, fourth and fifth principal component contributed for 10 , 8.9 and $7 \%$ of the total variations, respectively. The main traits that contributed for such variations in principal component three were number of spikelets per panicle, peduncle length, second culm diameter, and days to grain filling and maturity; whereas those contributed for principal component four were days to grain filling and maturity, peduncle length and lodging index. On the other hand, thousand kernel weight followed by days to grain filling

TABLE 9. Mean values for agronomical and morphological related traits of the seven clusters of tef genotype at Holetta, Debre Zeit and Alem Tena in Ethiopia

\begin{tabular}{|c|c|c|c|c|c|c|c|}
\hline \multirow[t]{2}{*}{ Traits } & \multicolumn{7}{|c|}{ Clusters } \\
\hline & I & II & III & IV & $\mathrm{V}$ & VI & VII \\
\hline Days to heading & 45.93 & 47.63 & 50.97 & 46.72 & 52.04 & 48.66 & 45.93 \\
\hline Grain filling period (days) & 52.19 & 52.36 & 50.51 & 58.56 & 54.48 & 49 & 52.19 \\
\hline Days to maturity & 98.12 & 99.87 & 101.32 & 105.28 & 106.15 & 97.69 & 98.12 \\
\hline Plant height $(\mathrm{cm})$ & 88.42 & 92.8 & 92.17 & 88.46 & 106.34 & 67.06 & 88.42 \\
\hline Culm length $(\mathrm{cm})$ & 54.93 & 58.51 & 56.09 & 56.92 & 63.24 & 40.15 & 54.93 \\
\hline Panicle length $(\mathrm{cm})$ & 33.5 & 34.21 & 36.21 & 31.34 & 43.09 & 26.97 & 33.5 \\
\hline Peduncle length $(\mathrm{cm})$ & 18.2 & 20.7 & 17.84 & 19.56 & 17.98 & 17.22 & 18.2 \\
\hline Second basal culm internode length $(\mathrm{cm})$ & 11.5 & 11.71 & 11.38 & 11.62 & 14.23 & 7.37 & 11.5 \\
\hline second basal culm internode diameter $(\mathrm{mm})$ & 2.07 & 2.11 & 2.04 & 1.96 & 2.21 & 1.88 & 2.07 \\
\hline number of spikelet per panicle & 330.17 & 322.48 & 383.57 & 226.96 & 442.97 & 269.38 & 330.17 \\
\hline Number of fertile tiller/plant & 3.54 & 3.28 & 3.28 & 3.13 & 3.01 & 3.19 & 3.54 \\
\hline Shoot biomass weight $(\mathrm{t} / \mathrm{ha})$ & 12.35 & 13.01 & 12.26 & 11.8 & 15.87 & 7.76 & 12.35 \\
\hline Grain yield per hectare $(\mathrm{t} / \mathrm{ha})$ & 3.79 & 3.69 & 3.16 & 3.53 & 4.29 & 2.11 & 3.79 \\
\hline Harvest index $(\%)$ & 29.72 & 27.34 & 24.34 & 28.94 & 25.81 & 25.9 & 29.72 \\
\hline Lodging index (\%) & 67.5 & 59.64 & 68.08 & 65.28 & 64.5 & 59.45 & 67.5 \\
\hline Thousand kernel weight (mg) & 27.68 & 25.85 & 25.58 & 28.81 & 26.97 & 27.46 & 27.68 \\
\hline
\end{tabular}


TABLE 10. Pair-wise generalised square distance $\left(\mathrm{D}^{2}\right)$ among seven clusters constructed from 28 tef genotypes

\begin{tabular}{lllllll}
\hline Clusters & 1 & 2 & 3 & 4 & 5 & 6 \\
\hline 1 & 0 & & & & & \\
2 & $68.10^{* *}$ & 0 & & & & \\
3 & $129.69^{* *}$ & $45.31^{* *}$ & 0 & & & \\
4 & $83.88^{* *}$ & $88.46^{* *}$ & $219.10^{* * *}$ & 0 & & \\
5 & $58.28^{* *}$ & $49.41^{* *}$ & $77.18^{* *}$ & $111.37^{* *}$ & 0 & \\
6 & $501.61^{* *}$ & $365.11^{* *}$ & $223.22^{* *}$ & $602.71^{* *}$ & $462.55^{* *}$ & 0 \\
\hline
\end{tabular}

$*$, ** = significant at $\mathrm{P} \leq 0.05$ and $\mathrm{P} \leq 0.01$, respectively

TABLE 11. Eigenvectors and Eigen values of the first five principal components for 16 traits of 28 tef genotypes

\begin{tabular}{|c|c|c|c|c|c|}
\hline \multirow[t]{2}{*}{ Traits } & \multicolumn{5}{|c|}{ Eigenvectors } \\
\hline & $\mathrm{PC} 1$ & PC2 & PC3 & $\mathrm{PC} 4$ & PC5 \\
\hline Days to heading & 0.166 & 0.503 & -0.028 & 0.070 & 0.050 \\
\hline Days to grain filling & 0.161 & -0.196 & -0.363 & 0.475 & -0.329 \\
\hline Days to maturity & 0.235 & 0.212 & -0.320 & 0.417 & -0.213 \\
\hline Plant height $(\mathrm{cm})$ & 0.377 & -0.023 & 0.027 & -0.067 & 0.082 \\
\hline Culm length $(\mathrm{cm})$ & 0.354 & -0.100 & -0.109 & -0.141 & 0.056 \\
\hline Panicle length $(\mathrm{cm})$ & 0.325 & 0.089 & 0.209 & 0.047 & 0.099 \\
\hline Peduncle length $(\mathrm{cm})$ & 0.109 & -0.174 & -0.439 & -0.438 & -0.120 \\
\hline Second culm length $(\mathrm{cm})$ & 0.366 & -0.078 & -0.054 & -0.032 & 0.083 \\
\hline Second culm diameter $(\mathrm{mm})$ & 0.223 & -0.058 & 0.397 & -0.006 & -0.262 \\
\hline Number of fertile tiller & 0.286 & 0.210 & 0.282 & -0.015 & 0.150 \\
\hline Number of spikelet per panicle & -0.085 & -0.290 & 0.458 & 0.198 & -0.030 \\
\hline Shoot biomass weight $\left(\mathrm{t} \mathrm{ha}^{-1}\right)$ & 0.363 & -0.130 & 0.101 & -0.034 & -0.101 \\
\hline Grain yield per hectare $\left(\mathrm{t} \mathrm{ha}^{-1}\right)$ & 0.301 & -0.340 & 0.047 & -0.069 & 0.005 \\
\hline Harvest index $(\%)$ & -0.049 & -0.521 & -0.089 & -0.097 & 0.163 \\
\hline Thousand seed weight (mg) & 0.071 & -0.012 & -0.199 & 0.191 & 0.812 \\
\hline Lodging index $(\%)$ & -0.056 & -0.271 & 0.079 & 0.534 & 0.122 \\
\hline Eigen values & 6.60 & 2.86 & 1.60 & 1.43 & 1.12 \\
\hline Percent variation explained & 41.3 & 17.80 & 10.0 & 8.90 & 7.0 \\
\hline Cumulative $\%$ of total variance explained & 41.30 & 59.10 & 69.10 & 78.0 & 85.0 \\
\hline
\end{tabular}

and second culm diameter were the major traits contributed for the variations exhibited for principal component five.

\section{DISCUSSION}

Ranges of traits. The substantial variability among the tef genotypes for several agronomic and morphological traits (Tables 2, 3 and 4) could be due to gene recombination or reshuffling resulting from mutagenesis and subsequent crossings. The significant mean square due to locations indicates that the locations were contrasting and adequate for the evaluation of the genotypes. Furthermore, the highly significant genotype by environment interaction effects revealed differential performances of the test genotypes across the locations. Hence, further evaluation of the genotypes under the environment where they perform well will enable their recommendation for specific release. Previous works using various sets of tef genotypes, including germplasm accessions (Assefa et al., 1999), 
released varieties (Jifar et al., 2015a), and elite brown seed genotypes (Jifar et al., 2015b) indicated the existence of significant variability for diverse traits due to genotype, location, and genotype by location interaction effects on different traits. Besides, highly significant genotype by location interactions was also reported for days to heading, whole culm and second culm length, second culm internode diameter, peduncle length and harvest index (Assefa et al., 2000). The significant genotype by environment interaction for days to heading in the present study could probably reveal the presence of high level of phenotypic plasticity in tef genotypes.

RIL-91 gave significantly higher plant height, culm and panicle length, and the highest number of spikelets per panicle, shoot biomass and grain yield compared to all the tef genotypes tested. Also, it exhibited moderately thicker second basal culm internode diameter and low lodging index (Tables 3 and 4). A genotype like RIL-91 possessing these desirable traits is suggested for fast track release and to be used as a parental line for future tef breeding programmes. Thus, the high number of spikelets per panicle, as well as high shoot biomass and grain yields of this particular genotype will play a key role in developing varieties with superior yield. Similarly, the thick culm internode and low lodging index of the same genotype will be a cornerstone towards developing tef cultivars with substantial tolerance to lodging. The development of new varieties for these vital traits can be made through methods which involve stringent selection procedures and/ or crossing to popular improved varieties.

RIL-244 and RIL-11 also had the second and third highest grain yield (Table 3), and intermediate number of days to heading and maturity. The performance of the yield-related traits of these three genotypes were even better than Quncho, popular tef variety in high potential areas and by far better than Tsedey, a widely cultivated variety in moisture-limited areas in Ethiopia (Assefa et al. 2011). This study, therefore, suggests the possibility of promoting RIL-91 for moisture-unlimited and high potential areas, while RIL-244 and RIL11 for both high potential and average environments in Ethiopia. On the other hand, RIL-302 with its shortest plant height, culm length, and second basal culm can be the right candidate towards developing tef varieties with lodging resistance. Besides, RIL-132 which is also among the high yielding genotypes and had the largest diameter of the second basal culm internode, would play a key role to further improve grain yield and to tackle the problem of lodging.

Regarding the test locations, Holetta had the longest phonologic traits compared to the other two locations (Tables 3 and 4). This is partly due to the long growing season at Holetta which is associated with cooler and higher rainfall environment than the other two locations (Materials and Methods). At Debre Zeit, the majority of the studied traits $(70 \%)$ showed the highest performance. This might be due to the favourable condition for tef growth on the black soil of Debre Zeit which has high water holding capacity. On the other hand, at Alem Tena, drought-prone location characterised by frequent crop failures due to moisture scarcity, only culm length had the highest values. Hence, the sub-optimal condition at Alem Tena negatively affect the majority of agronomical and morphological traits of tef. Despite obvious negative effects on major traits of tef at Alem Tena, this particular site will continue to serve as the best site to breed for varieties with drought tolerance.

Estimates of genetic variability. The high GCV values estimated for some of the traits in this study (Table 6) indicates the presence of considerable diversity for those traits among the tef genotypes examined. The range of variations estimated for both PCV $(0.004$ to $255.4 \%)$ and GCV (0.002 to173.9\%) in the current work were greater than previous 
reports of 6.1 to $40.2 \%$ for PCV and 3.0 to $22.1 \%$ for GCV by Assefa et al. (1999) or 2 to $58 \%$ for PCV and less than 1 to $35 \%$ for GCV by Assefa et al. (2000). Besides, the value of the present finding is much higher than the estimated range of 4.3 to 21.7 for PCV and 4.0 to $20.3 \%$ for GCV by Jifar et al. (2015a).

High genetic advance, coupled with high heritability values (Table 6) revealed that the heritability of those traits was mainly due to additive gene effects and, hence, selection may be effective to improve those traits. However, high heritability, accompanied with low genetic advance, indicates such high heritability of a given trait is mainly due to favourable influence of the environment rather than the genotype. The broad sense heritability estimates obtained in this study are commensurate with other earlier studies (Assefa et al. 1999; Assefa et $a l .$, 2000). However, our results were also either slightly higher (Tilahun et al., 2012), or lower (Jifar et al. 2015a; Jifar et al., 2015b) than earlier studies. These discrepancies could be due to the differences in the test genotypes and environments used.

Association of traits. The existence of positive associations (Table 6) among traits indicates that improving one of them would bring an improvement in the other trait. This indicates that selection for such related traits can be made based on only those traits that can be assesses relatively easily. The positive and significant association detected among grain yield and that of shoot biomass and harvest index in this study is in line with the findings of several researchers (Chanyalew et al., 2006; Chanyalew et al., 2009; Jifar and Assefa, 2013; Jifar et al., 2015a; Jifar et al., 2015b). This indicates the relatively consistent association of the tef traits in various studies. Similarly, the positive and significant phenotypic association of lodging index with days to heading and maturity is in line with Jifar et al. (2015b) but contrary to Jifar et al. (2015a) with respect to the direction of association. These contrasting relationships between lodging index and days to heading was due to the differences in the type of tef varieties used in the two experiments. Varieties with long heading time are more vulnerable to lodging due to longer period of exposure to wind and rain while those with shorter heading time score lower degree of lodging. Besides, Chanyalew et al. (2009) also reported a positive and significant phenotypic association between lodging index and grain yield. This indicates that the problem of lodging is more severe in high yielding than in low yielding genotypes since the heavy weight of the panicles in high yielders contributes to the lodging inducing torque or force.

Cluster and divergence analysis. Among the seven distinct clusters, genotypes in cluster 5 were characterised to have high grain yield accompanied with longest days to heading and maturity that enable to address varietal development and release in high potential environments. High yielding genotypes are usually late maturing types and are suitable for areas with optimum rainfall and long growing period.

Genotypes in cluster 5 had the highest number of spikelet per panicle, shoot biomass and grain yield; whereas those in cluster 4 had the highest 1000-kernel weight. In addition to those in cluster 5 and 4, genotypes in cluster $1 \mathrm{had}$ the shortest days to heading and to maturity, the highest number of fertile tillers and the harvest index value. Such desirable traits observed in these clusters are important for further improvement of yield related traits of tef.

Existence of maximum amount of genetic recombination and genetic segregation is generally suggested for crosses being made between clusters with maximum distances. Thus, crosses of tef genotypes from cluster 4 and 6 will enable us to get maximum recombination, based on the present investigation. The total number of clusters investigated in this study is similar to the works of Jifar et al. (2015a) who used 36 brown 
seeded tef genotypes based on ten yield related traits. Another closer result was reported by Plaza-Wüthrich et al. (2013) who obtained six distinct clusters based on ten traits using 18 tef genotypes (15 landraces and three improved varieties). Though the number of genotypes studied varied for diverse studies, this cluster analysis generally revealed the existence of significant genetic variation that can be utilised for further tef improvement.

Principal component analysis. Based on principal components analysis (Table 11), the total variation that was explained in the present study $(85 \%)$ was higher than that of PlazaWüthrich et al. (2013), who reported $79.6 \%$ for the first four principal components with eigenvalue greater than one. Similarly, it was higher than that of Assefa et al. (1999) and Jifar et al. (2015a), who reported a value of 73.7 and $78.3 \%$ for the first four and first three principal components with eigenvalue greater than one, respectively. However, the variability explained by the first principal component $(41.3 \%)$ in the present study is almost similar with Jifar et al. (2015a); Plaza-Wüthrich et al. (2013); Assefa et al. (1999) who reported 44. 7, 39.7 and $34.4 \%$ respectively using different sets of tef germplasm. Generally, this indicates that most of the variation in phenology and morpho-agronomic traits of tef can be explained on the basis of the first two to three or four principal components.

On the other hand, variations in plant height, second culm and whole culm length were the main contributors for the gross variation explained by principal component one $(41.3 \%$ ) while variations in days to heading and maturity, grain yield and number of spikelet per panicle had mainly contributed to second principal component (17.8\%). The remaining traits were also mainly contributing to principal component 3, 4 and 5, respectively. The result, therefore, revealed that tef is a very versatile and complex species whereby almost all the studied traits appeared to have high contributions towards the gross phenotypic variability present among the genotypes.

\section{CONCLUSION}

Results of evaluation of some promising lines of tef for lodging and yield improvement reveal that grain yield is significantly and positively associated with all traits, except days to heading and to maturity; peduncle length, number of fertile tillers, lodging and 1000kernel weight. This suggests the possibility of improving grain yield by considering any one of the associated traits.

Cluster analysis groups the 28 tef genotypes into six distinct clusters, of which $32.1 \%$ was grouped in cluster 1 , followed by cluster $2(25 \%)$. The first five principal components with eigenvalues greater than one accounts for $85 \%$ of the total variations among the genotypes investigated.

In general, the existence of considerable variations for all traits of the test genotypes have been detected. Thus, genotypes like RIL 91 (a cross between Quncho and kinde) has significantly longer panicle, higher number of spikelet per plant, as well as the highest shoot biomass and grain yield. Besides, RIL-244 and RIL-11, both from the crosses of kinde by Kaye Murri, are ranked the second and third high yielding genotypes, with relatively shorter days to heading and to maturity. Genotypes identified with better grain yield related traits and reasonable lodging tolerance require further evaluation and eventual release to the farming communities in tef growing environments in Ethiopia.

\section{ACKNOWLEDGEMENT}

The authors acknowledge the Ethiopian Institute of Agricultural Research (EIAR), Syngenta Foundation for Sustainable Agriculture and University of Bern for financial and technical support. Technical support from the tef breeding programme at Holetta, Debre 
Zeit Agricultural Research Centres and Alem Tena Research Substation is appreciated.

\section{REFERENCES}

Allard, R.W. 1960. Principles of Plant Breeding. John Wiley \& Sons, New York, USA.

Assefa, K., Ketema, S., Tefera, H., Hundera, F. and Kefyalew, T. 2001. Genetic diversity for agronomic traits in tef. In: Tefera, $\mathrm{H}$, Belay, G. and Sorrells, M. (Eds.), Narrowing the Rift: Tef Research and Development. Ethiopian Institute of Agricultural Research, Addis Ababa, Ethiopia. pp. 33-47.

Assefa, K., Ketema, S., Tefera, H., Kefyalew, T. and Hundera, F. 2000. Trait diversity, heritability and genetic advance in selected germplasm Lines of tef [Eragrostis tef (Zucc.) Trotter]. Hereditas 133:29-37.

Assefa, K., Ketema, S., Tefera, H., Nguyen, H.T., Blum, A., Ayele, M., Bai, G., Simane, B. and Kefyalew, T. 1999. Diversity among germplasm lines of the Ethiopian cereal tef [Eragrostis tef (Zucc.) Trotter]. Euphytica 106:87-97.

Assefa, K., Yu, J.K., Zeid, M., Belay, G., Tefera, H. and Sorrells, M.E. 2011. Breeding tef [Eragrostis tef (Zucc.) Trotter]: conventional and molecular approaches. Plant Breeding 130:1-9.

Assefa, K., Aliye, S., Belay, G., Metaferia, G., Tefera, H., Sorrells, M.E. 2011. Quncho: the first popular tef variety in Ethiopia. International Journal of Agricultural Sustainability 9:25-34.

Bediye, S., Sileshi, Z. and Mengiste, T. 1996. Tef [Eragrostis tef (Zucc.) Trotter] straw quality as influenced by variety and locations. Ethiopian Society of Animal Production (ESAP), Addis Ababa, Ethiopia. pp. 145-152.

Burton, G.W. and Devane, E.H. 1953. Estimation of heritability in tall Festuca (Festuca arundinacea) from replicated clonal material. Agronomy Journal 45:478481.
Caldicott, J. and Nuttall, A. 1979. A method for the assessment of lodging in cereal crops. Journal of the National Institute of Agricultural Botany 15:88-91.

Chanyalew, S., Tefera, H., Zelleke, H. and Singh, H. 2006. Correlation and path coefficient analysis of yield related traits in recombinant inbred lines of tef (Eragrostis tef). Journal of Genetics and Breeding 60:209-216.

Chanyalew, S., Tefera, H. and Singh, H. 2009. Genetic variability, heritability and trait relationships in recombinant inbred lines of tef [Eragrostis tef (Zucc.) Trotter]. Research Journal of Agriculture and Biological Sciences 5:474-479.

CSA. 2015. Agricultural Sample Survey for 2014/15. Report on area and production of major crops (Private Peasant Holdings, Meher Season). Central Statistical Agency (CSA), Addis Ababa, Ethiopia.

Ebba, T. 1969. Tef (Eragrostis tef): The cultivation, usage and some of the known diseases and insect pests. Addis Ababa University, College of Agriculture, Dire Dawa, Ethiopia.

Esfeld, K., Uauy, C. and Tadele, Z. 2013. Application of TILLING for orphan crop improvement. In: Jain, S.M. and Gupta, S.D. (Eds.). Biotechnology of neglected and underutilized crops. Springer Science, Dordrecht. pp. 83-113.

Gomez, K. and Gomez, A. 1984. Statistical Procedures for Agricultural Research. John Wiley \& Sons. New York, USA.

Jifar, H. and Assefa, K. 2013. Variation and association of yield and yield related traits in released tef [Eragrostis tef (Zucc.) Trotter] varieties evaluated during offseason in Ethiopia. Journal of Agriculture and Development 3:18-33.

Jifar, H., Assefa, K. and Tadele, Z. 2015a. Grain yield variation and association of major traits in brown-seeded genotypes of tef [Eragrostis tef (Zucc.) Trotter]. Agriculture and Food Security 4:7. 
Jifar, H., Bekele, E. and Assefa, K. $2015 b$. Genetic variability, heritability and association of traits in released tef [Eragrostis tef (Zucc.) Trotter] varieties evaluated in Southwestern and Central Ethiopia. Journal of Science and Sustainable Development 3:19-31.

Jost, M., Esfeld, K., Burian, A., Cannarozzi, G., Chanyalew, S., Kuhlemeier, C., Assefa, K. and Tadele, Z. 2015. Semi-dwarfism and lodging tolerance in tef (Eragrostis tef) is linked to a mutation in the alpha-Tubulin 1 gene. Journal of Experimental Botany 66:933-944.

Ketema, S. 1993. Tef (Eragrostis tef): Breeding, Genetic Resources, Agronomy, Utilization and Role in Ethiopian Agriculture. Institute of Agricultural Research (IAR), Addis Ababa, Ethiopia.

Million, F. 2012. Variability, heritability and association of some morpho-agronomic traits in field pea (Pisum sativum L.) genotypes. Pakistan Journal of Biological Sciences 15:358-366.

Mintab. 2007. Minitab Statistical Software. Release 15 ed. Minitab Inc., State College, Pennsylvania, USA.

MOA 2014. Crop Variety Register Issue No. 17. Ministry of Agriculture, Plant Variety Release, Protection and Seed Quality Control Directorate, Addis Ababa, Ethiopia.

Plaza-Wüthrich, S.W., Cannarozzi, G. and Tadele, Z. 2013. Genetic and phenotypic diversity in selected genotypes of tef [Eragrostis tef (Zucc.) Trotter. African Journal of Agricultural Research 8:10411049.

SAS 2002. SAS Property Software. SAS Institute, Cary, USA.

Singh, R.K. and Chaudhary, B.D. 1996. Biometrical Methods in Quantitative Genetic Analysis. Kalyani, Ludhiana, India.
Spaenij-Dekking, L., Kooy-Winkelaar, Y. and Koning, F. 2005. The Ethiopian Cereal Tef in Celiac Disease. The New England Journal of Medicine 353:1748-1749.

Tadele, Z., Mba, C. and Till, B.J. 2010. TILLING for mutations in model plants and crops. In: Jain, S.M. and Brar, S.D. (Eds.). Molecular techniques in crop improvement. Springer, The Netherlands. pp. 307-332.

Tavassoli, A. 1986. The cytology of Eragrostis tef with special reference to $E$. tef and its relatives. M.Sc Thesis, University of London, UK.

Tefera, H. and Ketema, S. 2001. Production and importance of tef in Ethiopian agriculture. In: Tefera, H, Belay, G. and Sorrells, M. (Eds.). Narrowing the rift: Tef research and development. Ethiopian Institute of Agricultural Research, Addis Ababa, Ethiopia. pp. 3-7.

Tefera, H., Assefa, K., Hundera, F., Kefyalew, T. and Tefera, T. 2003 Heritability and genetic advance in recombinant inbred lines of tef (Eragrostis tef). Euphytica 13:9196.

Tilahun, A., Ayana, A. and Zeleke, H. 2012. Genetic divergence, trait association and path analysis of tef (Eragrostis tef (Zucc.) Trotter) lines. World Journal of Agricultural Science 8:642-646.

Vavilov, N. 1951. The origin, variation, immunity and breeding of cultivated plants. Translated from the Russian by K. Starrchester, The Ronald Press Co. New York, USA.

Zhu, Q., Smith, S.M., Ayele, M., Yang, L., Jogi, A., Chaluvadi, S.R. and Bennetzen, J.L. 2012. High-throughput discovery of mutations in tef semi-dwarfing genes by next-generation sequencing analysis. Genetics 192:819-829. 